\title{
RARA/ZBTB16 Fusion Gene
}

National Cancer Institute

\section{Source}

National Cancer Institute. RARA/ZBTB16 Fusion Gene. NCI Thesaurus. Code C99372.

A fusion gene that results from a chromosomal translocation $t(11 ; 17)(q 23 ; q 21)$ which fuses the exon 3 of the RARA gene to the 3' portion of the ZBTB16 gene. This rearrangement is associated with acute promyelocytic leukemia. 